\title{
Effect of laparoscopic ovarian drilling on serum anti-Mullerian hormone in clomiphene citrate resistant polycystic ovarian syndrome patients
}

\author{
Ambika Shankar*, Oby Nagar, Shakuntla, Suman Meghwal
}

Department of Obstetrics and Gynaecology, SMS Medical College, Jaipur, Rajasthan, India

Received: 03 July 2021

Revised: 27 July 2021

Accepted: 28 July 2021

\section{*Correspondence:}

Dr. Ambika Shankar,

E-mail: ambika1993@gmail.com

Copyright: $@$ the author(s), publisher and licensee Medip Academy. This is an open-access article distributed under the terms of the Creative Commons Attribution Non-Commercial License, which permits unrestricted non-commercial use, distribution, and reproduction in any medium, provided the original work is properly cited.

\begin{abstract}
Background: PCOS (polycystic ovarian syndrome) is the most common cause of anovulatory infertility, the purpose of our study was to see the effect of laparoscopic ovarian drilling on the ovarian reserve (with AMH as an indicator of ovarian reserve) and its safety as 2 nd line of treatment in patients resistant to clomiphene citrate.

Methods: This was a prospective interventional study conducted on 40 clomiphene citrate resistant PCOS women attending the infertility OPD. This study was conducted over a period of 1 year May 2019 to May 2020. Laparoscopic ovarian drilling (LOD) was done and these subjects were studied preoperatively and postoperatively on day 7 and day 30 for change in AMH (anti-Mullerian hormone) levels.

Results: There is a significant change in the AMH level post LOD day 7 and 30 but not so severe that it will lead to premature ovarian failure. The amount of drop in AMH (day 30) increases till $20 \mathrm{ng} / \mathrm{ml}$ beyond which it shows a decrease.

Conclusions: If LOD is done in a proper manner in women with sufficient ovarian reserve (high AMH), it will not adversely affect the ovarian reserve (the fall is not enough to cause premature ovarian insufficiency).
\end{abstract}

Keywords: PCOS, Anti-Mullerian hormone, Laparoscopic ovarian drilling

\section{INTRODUCTION}

PCOS is the lifestyle change induced pandemic of reproductive age group women. It is the most common endocrinopathy affecting $4-12 \%$ of the reproductive age group women. ${ }^{1}$ Not only does it have an adverse effect on the fertility but also on the quality of life. It was first described in 1935 by American gynecologists Stein and Levanthal. The European society for human reproduction and embryology (ESHRE) and American society for reproductive medicine (ASRM) gave the Rotterdam's criteria, which defined PCOS as the presence of at least two out of the following three criteria: oligomenorrhea and/or amenorrhea, hyperandrogenism (clinical and/or biochemical), polycystic ovaries assessed by ultrasound (FNPO 12 follicles of 2-9 mm and/or ovarian volume of $10 \mathrm{~cm}^{3}$ ), excluding Cushing's syndrome, androgen producing tumors or congenital adrenal hyperplasia. ${ }^{2,3}$

Pathophysiology of PCOS is associated with an endogenous LH hypersecretion and increase in LH:FSH (luteinizing hormone:follicule stimulating hormone) $>2$. LH strongly stimulates intraovarian androgen production by acting on the ovarian theca cells, converting the estrogenic environment to an androgenic environment interfering with folliculogenesis. Hence surgical reduction in the amount of theca cells can also be used as a mode of induction of ovulation in cases of failure of medical induction of ovulation. 
Anovulation is the cause of infertility in PCOS. In patients in whom clomiphene citrate the first line drug fails to induce ovulation, exogenous gonadotropins can be given or ovarian ablation by laparoscopic ovarian drilling can be done as a second line treatment. ${ }^{4,5}$ LOD avoids ovarian hyperstimulation syndrome, reduces costs and can be done in single sitting which is more appropriate for our low resource setup. ${ }^{6}$

Surgical reduction of ovarian volume was initially done by ovarian wedge resection which was associated with premature ovarian failure (POF), hence abandoned. Later it was reintroduced in an improvised manner as LOD where the ablation was done as a fixed number of holes with fixed doses of power to the ovary destroying only a fixed amount of tissue with the intention of reducing the risk of POF.

AMH, also known as Mullerian inhibiting substance, was known mainly as a substance involved in male sexual differentiation. Now it is known that AMH is also secreted in women, mainly secreted by the granulosa cells (GC) of ovarian early developing follicles. ${ }^{7} \mathrm{AMH}$ is now considered as a marker that can estimate the quantity and activity of recruitable follicles. AMH has been shown to be two to threefold higher in the serum and intrafollicularly in women with PCOS than in women with healthy ovaries. ${ }^{8}$ The AMH excess in PCOS is related to the increment in the number of pre-antral follicles.

The consistency of serum levels of AMH throughout the menstrual cycle, with very little inter cycle variability, makes it an attractive marker of response to treatment. ${ }^{9}$ With this background, we conducted an interventional and prospective study to evaluate the effect of LOD on plasma levels of AMH and its safety keeping its effect on ovarian reserve in mind as such a study has never been conducted in our region (Rajasthan).

\section{Aim}

The aim was to find the effect of LOD on plasma levels of AMH (marker of ovarian reserve) in PCOS patients who were clomiphene citrate resistant.

\section{METHODS}

This was a prospective interventional study conducted on 40 clomiphene citrate resistant PCOS women attending the infertility OPD of Zenana hospital, department of obstetrics and gynaecology, SMS medical college, Jaipur. This study was conducted over a period of 1 year May 2019 to May 2020. These subjects were studied preoperatively and postoperatively on day 7 and day 30 .

\section{Ethical clearance}

Institutional review board and ethical committee clearances were taken.

\section{Inclusion criteria}

Clomiphene citrate resistant PCOS patients of the age group of 20-35 years willing for LOD and giving consent for study with a pre-op AMH levels $\geq 1 \mathrm{ng} / \mathrm{ml}$ (good ovarian reserve) were included in the study.

\section{Exclusion criteria}

Patients with hyperprolactinemia, thyroid disease, diabetes, male factor infertility and unfit for anaesthesia/surgery were excluded from the study.

\section{Methodology}

Subjects were screened according to Rotterdam's criteria for PCOS and of them clomiphene citrate resistant patients (in whom there is failure to ovulate after clomiphene citrate administration of $150 \mathrm{mg}$ from day 2-6 of the cycle for at least 3 consecutive cycles) were chosen. ${ }^{5} 40$ clomiphene citrate resistant cases of PCOS undergoing infertility treatment, consenting for LOD as an option for treatment and willing to participate in the study were recruited, after applying the inclusion and exclusion criteria. Standardized data collection on a predesigned study proforma including history, clinical examination and relevant investigations was done. These patients were preoperatively subjected to thorough history taking and clinical examination. Height, Weight, waist and hip circumference were measure in the standardised manner to calculate body mass index (BMI) (Asian classification). Preoperative serum AMH levels from the central lab for all study subjects. The patients under went diagnostic hysterolaparoscopy and LOD between day 5-10 of their menstrual cycle or else after excluding pregnancy, if they were amenorrheic. Under general anaesthesia first diagnostic hysteroscopy followed by laparoscopy was done. LOD was done using a monopolar electrocautery needle, four punctures were made per ovary for 4 seconds up to $4 \mathrm{~mm}$ depth with the power (pure cutting) set at $40 \mathrm{~W}$. Follow up was done on day 7 post-LOD.This time coincided with suture removal ensuring a $100 \%$ follow up and this opportunity was used to perform post LOD AMH levels measurement. The serum AMH levels were again checked on day 2 of the first cycle or on the 35th day post-op day whichever was earlier.

\section{Statistical analysis}

Categorical/nominal variables were expressed as number and percentage and will be analyse using Chi square test. Continuous variables were expressed as mean and standard deviation and were analysed using paired $t$ test for comparison between at different times within the same group. Correlation between two continuous variables was assessed using Pearson correlation coefficient. A p value $<0.05$ was taken as statistically significant. All statistical analysis was done using Epi info version 7.2.1.0 statistical software. 


\section{RESULTS}

A total of 40 clomiphene citrate resistant PCOS women were included in study, their age ranged between 22 to 35 years and a mean age of $28.38 \pm 3.46$ (mean \pm SD) years. Most of the patients (55\%) resided in the urban area which can be attributed to higher awareness. Most of our subjects belong to the upper middle class socioeconomically $(35 \%)$, may be because obesity is more prevalent in the affluent society. The duration of infertility ranged between 3 to 10 years $(5.60 \pm 2.01$ years) and the average duration of active married life was $5.75 \pm 2.10$ (mean \pm SD) years. Mostly because of delay in acceptance of surgery for treatment of PCOS. Out of the 40 patients who underwent LOD, only 6 patients, that is, $15 \%$ percent of the population had regular menstrual cycles and others (75\%) had irregular cycles mostly oligo-menorrhea (62.5\%). $65 \%$ of them were overweight (BMI $25.1-29.9 \mathrm{~kg} / \mathrm{m}^{2}$ ) and obese $\left(\mathrm{BMI} \geq 30 \mathrm{~kg} / \mathrm{m}^{2}\right)$.

As seen in Table 1 the mean AMH at baseline (pre-op) was $14.37 \pm 5.12 \mathrm{ng} / \mathrm{ml}$, which decreased to $13.2 \pm 4.99 \mathrm{ng} / \mathrm{ml}$ on post op day 7 . This decline of $1.17 \pm 0.78 \mathrm{ng} / \mathrm{ml}$ in mean AMH from baseline to day 7 was found to be statistically significant $(\mathrm{p}<0.001)$. The mean AMH decreased further $10.37 \pm 4.09 \mathrm{ng} / \mathrm{ml}$ at post-op day 30. This decline of $4 \pm 2.08 \mathrm{ng} / \mathrm{ml}$ in mean AMH from baseline to day 30 was found to be statistically significant $(\mathrm{p}<0.001)$. Figure 1 depicts the change in serum $\mathrm{AMH}$ at different check points.

Table 1: Comparison of serum AMH of study subjects at different points of the study.

\begin{tabular}{|lllll|}
\hline Time point & N & AMH $($ mean \pm SD) & Change & P value (paired t test) \\
\hline Pre-op & 40 & $14.37 \pm 5.12$ & - & - \\
\hline Post-op day 7 & 40 & $13.2 \pm 4.99$ & $-1.17 \pm 0.78$ & $<0.001(\mathrm{~S})$ \\
\hline Post-op day 30 & 40 & $10.37 \pm 4.09$ & $-4 \pm 2.08$ & $<0.001(\mathrm{~S})$ \\
\hline
\end{tabular}

Table 2: Comparison of the 5 subgroups of the variable AMH (preoperative) in terms of change in AMH (day 30).

\begin{tabular}{|c|c|c|c|c|c|c|c|}
\hline \multirow{2}{*}{$\begin{array}{l}\text { Change in } \\
\text { AMH (day 30) }\end{array}$} & \multicolumn{5}{|c|}{ AMH (preoperative) } & \multicolumn{2}{|c|}{$\begin{array}{l}\text { Kruskal Wallis } \\
\text { test }\end{array}$} \\
\hline & $<6.8 \mathrm{ng} / \mathrm{ml}$ & $6.8-10 \mathrm{ng} / \mathrm{ml}$ & $\begin{array}{l}10-15 \\
\mathrm{ng} / \mathrm{ml}\end{array}$ & $\begin{array}{l}15-20 \\
\mathrm{ng} / \mathrm{ml}\end{array}$ & $\begin{array}{l}>20 \\
\mathrm{ng} / \mathrm{ml}\end{array}$ & $\chi^{2}$ & $\begin{array}{l}P \\
\text { value }\end{array}$ \\
\hline Mean (SD) & $\begin{array}{l}-0.40 \\
(0.15)\end{array}$ & $\begin{array}{l}-2.47 \\
(1.20) \\
\end{array}$ & $\begin{array}{l}-3.00 \\
(0.96)\end{array}$ & $\begin{array}{l}-5.88 \\
(4.11) \\
\end{array}$ & $\begin{array}{l}-5.70 \\
(2.06) \\
\end{array}$ & \multirow{3}{*}{19.258} & \multirow{3}{*}{0.001} \\
\hline Median (IQR) & $\begin{array}{l}-0.4 \\
(-0.45-0.34)\end{array}$ & $\begin{array}{l}-2.57 \\
(-3.24-1.39)\end{array}$ & $\begin{array}{l}-3.18 \\
(-3.83-2.12)\end{array}$ & $\begin{array}{l}-4.44 \\
(-6.71-3.66)\end{array}$ & $\begin{array}{l}-6.04 \\
(-7-4.65)\end{array}$ & & \\
\hline Range & $-0.5-0.29$ & $-3.98-1.16$ & $-4.14-1.56$ & $\begin{array}{l}-16.65- \\
2.72\end{array}$ & $\begin{array}{l}-8.38- \\
2.18\end{array}$ & & \\
\hline
\end{tabular}

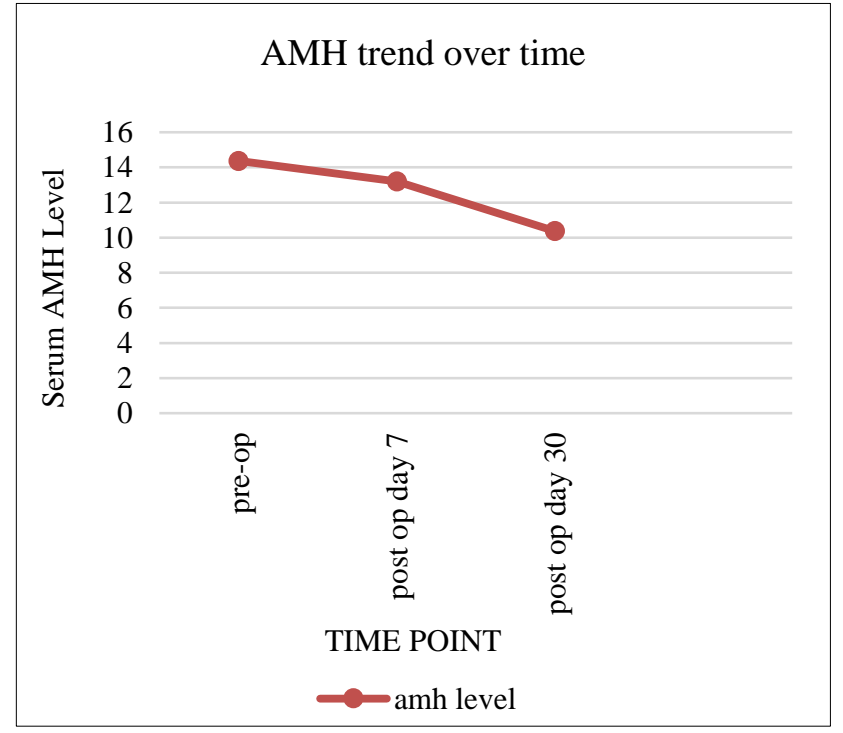

Figure 1: Serum AMH trend over time.

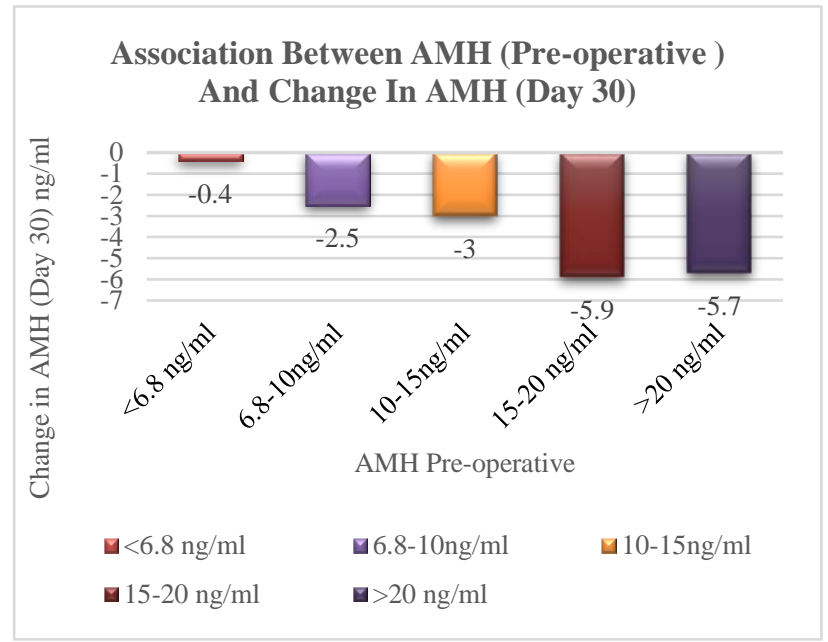

Figure 2: Mean change in AMH on day 30 in relation to pre-op AMH (drop in AMH increases till $20 \mathrm{ng} / \mathrm{ml}$ beyond which it shows a decrease). 
As seen in Table 2 the variable change in AMH (day 30) was not normally distributed in the 5 subgroups of the variable AMH (preoperative). Thus, non-parametric tests (Kruskal Wallis test) were used to make group comparisons. The mean (SD) of change in AMH (day 30) in the AMH (preoperative): $<6.8 \mathrm{ng} / \mathrm{ml}$ group was -0.40 (0.15), that in the AMH (preoperative): $6.8-10 \mathrm{ng} / \mathrm{ml}$ group was -2.47 (1.20), of the AMH (preoperative): $10-15 \mathrm{ng} / \mathrm{ml}$ group was -3.00 (0.96), of the AMH (preoperative): 15-20 $\mathrm{ng} / \mathrm{ml}$ group was -5.88 (4.11), of the AMH (preoperative): $>20 \mathrm{ng} / \mathrm{ml}$ group was -5.70 (2.06). There was a significant difference between the 5 groups in terms of change in AMH (day 30) $\left(\chi^{2}=19.258, p=0.001\right)$. Figure 2 depicts the drop in AMH increases till $20 \mathrm{ng} / \mathrm{ml}$ beyond which it shows a decrease.

\section{DISCUSSION}

PCOS is considered to be a significant cause of anovulatory infertility. It is responsible for $80 \%$ of cases of infertility due to anovulation. ${ }^{3}$ Oral ovulation induction agents are the first line therapy in PCOS patients, however patients who failed to respond can either be treated medically with gonadotropins ovulation induction or surgically with LOD. Gonadotropin therapy is expensive, requires frequent monitoring and carries the risk of multiple gestation and ovarian hyper-stimulation syndrome. ${ }^{6}$

In this study, the mean of preoperative serum AMH level was $(14.37 \mathrm{ng} / \mathrm{ml})$ which was high when compared with normal value of women in reproductive age with normal menstruation, this agreed with a study done by Broer et al. ${ }^{10}$ Studies by Weerakiet et al and Maheshwari et al also showed similar finding, showing that women with PCOS have 2-3 times higher than normal level of serum AMH concentration, which was related to increment in the number of small follicles. ${ }^{11,12}$ The higher levels in this study compared to that seen in in the studies by Saraswat et al and Elmashad et al was possibly due to the selection of patients with clomiphene resistant PCOS. ${ }^{13,14}$ These patients were known to have high serum AMH levels which was cited as one of the reasons for not responding to medical methods of ovulation induction.

In this study, we reported a significant reduction in the serum AMH level from $14.37 \pm 5.12 \mathrm{ng} / \mathrm{ml}$ to $13.2 \pm 4.99$ $\mathrm{ng} / \mathrm{ml}, 7$ day post LOD and further to $10.37 \pm 4.09 \mathrm{ng} / \mathrm{ml}$, 30 days after doing the LOD operation and this was due to reduction in the number of AFC (only source of AMH) caused by thermal destruction to the ovarian tissue. This was similar to that reported by Amer et al and Ali et al and in contrast to the study by Paramuet al.15-17. So, it could be hypothesized that the fall in serum AMH resulting from LOD could lead to an increase in follicular responsiveness to circulating $\mathrm{FSH}$, thus allowing further growth and selection of a dominant follicle.

In this study 30-35 days after LOD, serum level of AMH was found to be lower than its level before LOD and this level stayed higher than normal when compared with normal women without PCOS, agreed with Farzadi et al. ${ }^{18}$ Thus we can conclude that, LOD had normalized ovarian function which was a significant factor in the follicular recruitment and their maturation. Therefore, LOD has no negative effect on ovarian reserve. This meant that if the operation was done properly, it will not result in reduction of ovarian reserve which is in agreement with Amer et al. ${ }^{19}$ Elmashad et al showed that serum AMH remained low for 6 month of follow up while Farzadi et al showed that after an initial drop in $\mathrm{AMH}$, it recovered by 6 months.

In this study the amount of drop in the serum $\mathrm{AMH}$ on postoperative day 30 increased till preoperative serum AMH level of $20 \mathrm{ng} / \mathrm{ml}$ beyond which it showed a decline, agreeing with Saraswat et al to a certain extent. This had to be studied in a larger study population to confirm beyond level of serum AMH, LOD was less responsive. Preoperative measurements of serum AMH levels for women who are candidates to underwent LOD was suggested to be beneficial to determine their likelihood of response and can be used a useful marker for prediction of ovulation after LOD as seen by Amer et al. ${ }^{19}$ It was thought that normal levels of serum AMH were necessary to achieve optimal ovarian responsiveness to ovulation induction. Both low and high levels of AMH seemed to be detrimental to ovarian responsiveness to stimulation. ${ }^{20,21}$

A longer follow up with a larger study group may reveal more.

\section{CONCLUSION}

LOD is an effective second line treatment for infertile PCOS women who are not responding to medical treatment (clomiphene citrate). Post LOD a significant fall in serum AMH is noted, which is still higher than a women without PCOS, that is there is a normalization of the AMH level, which is needed for progression of folliculogenesis. If LOD is done in a proper manner in women with sufficient ovarian reserve (high $\mathrm{AMH}$ ), it will not adversely affect the ovarian reserve (the fall is not enough to cause premature ovarian insufficiency).

\section{Funding: No funding sources}

Conflict of interest: None declared

Ethical approval: The study was approved by the Institutional Ethics Committee

\section{REFERENCES}

1. Yildiz BO, Bozdag G, Yapici Z, Esinler I, Yarali H. Prevalence, phenotype and cardiometabolic risk of polycystic ovary syndrome under different diagnostic criteria. Hum Reprod. 2012;27(10):3067-73.

2. Chang J, Azziz R, Legro R, Dewailley D, Franks S, Tarlatzis BC, et al. The Rotterdam ESHRE/ASRMsponsored PCOS consensus workshop group (2004) revised 2003 consensus on diagnostic criteria and 
long-term health risks related to polycystic ovary syndrome (PCOS). Fertil Steril. 2004;81(1):19-25.

3. Balgen A. Polycystic ovary syndrome and secondary amenorrhoea. In: Edmonds DK, Lees C, Bourne T, eds. Dewhurt's textbook of Obestetric and Gynaecology. 8th ed. John Wiley and Sons Ltd; 2012: 513-33.

4. Bhagavath B, Carson SA. Ovulation induction in women with polycystic ovary syndrome: an update. Am J Obstet Gynecol. 2012;206(3):195-8.

5. Badawy A, Mosbah A, Shady M. Anastrozole or letrozole for ovulation induction in clomipheneresistant women with polycystic ovarian syndrome: a prospective randomized trail. Fertil Steril. 2008;89(5):1209-12.

6. Gadir AA, Mowafi RS, Alnaser HM, Alrashid AH, Alonezi OM, Shaw RW. Ovarian electrocautery versus human menopausal gonadotrophins and pure follicle stimulating hormone therapy in the treatment of patients with polycystic ovarian disease. Clin Endocrinol (Oxf). 1990;33(5):585-92.

7. Marca AL, Broekmans FJ, Volpe A, Fauser BC, Macklon NS, ESHRE special interest group for reproductive endocrinology-AMH round table. AntiMullerian hormone (AMH): what do we still need to know? Hum Reprod. 2009;24(9):2264-75.

8. Pigny $\mathrm{P}$, Merlen E, Robert Y, Cortet-Rudelli C, Decanter C, Jonard S, et al. Elevated serum level of anti-Mullerian hormone in patients with polycystic ovary syndrome: relationship to the ovarian follicle excess and to the follicular arrest. J Clin Endocrinol Metab. 2003;88(12):5957-62.

9. Lambert-Messerlian G, Plante B, Eklund EE, Raker C, Moore RG. 2016 Levels of antimüllerian hormone in serum during the normal menstrual cycle. Fertil Steril. 2016;105(1):208-13.

10. Broer SL, Broekmans FJ, Laven JS, Fauser BC. Anti Müllerian hormone: ovarian reserve testing and its potential clinical implication. Hum Reprod Update. 2014;20(5):688-701.

11. Weerakiet S, Lertvikool S, Tingthanatikul $\mathrm{Y}$, Wansumrith S, Leelaphiwat S, Jultanmas R. Ovarian reserve in women with polycystic ovary syndrome who underwent laparoscopic ovarian drilling. Gynecol Endocrinol. 2007;23(8):455-60.

12. Maheshwari A, Gibreel A, Bhattacharya S, Johnson N. Dynamic tests of ovarian reserve: a systematic review of diagnostic accuracy. Reprod Biomed Online. 2009;18(5):717-34.
13. Saraswat M, Jose T, Rajput M, Siddique N. Impact of laparoscopic ovarian drilling on anti-mullerian hormone levels in women with clomiphene resistant polycystic ovary syndrome. Indian J Obstet Gynecol Res. 2017;4(3):297-300.

14. Elmashad A. Impact of laparoscopic ovarian drilling on anti-Mullerian hormone levels and ovarian stromal blood flow using three dimensional power Doppler in women with anovulatory polycystic ovary syndrome. Fertil Steril. 2011;95(7):2342-6.

15. Amer S, Li TC, Ledger WL. Ovulation induction using laparoscopic ovarian drilling in women with polycystic ovarian syndrome: predictors of success. Hum Reprod. 2004;19(1):719-24.

16. Al-Assadi AF, Dhamia S. The effect of laparoscopic ovarian drilling on the serum levels of AMH, FSH, LH and testosterone hormones, in patients with PCOS. Med J Basrah Univ. 2019.

17. Paramu S. Impact of laparoscopic ovarian drilling on serum anti-Mullerian hormone levels in patients with anovulatory polycystic ovarian syndrome. Turk J Obstet Gynecol. 2016;13:203-7.

18. Farzadi L, Nouri M, Ghojazadeh M, Mohiti M, Aghadavod E. Evaluation of ovarian reserve after laparoscopic surgery in patients with polycystic ovary syndrome. Bio Impact. 2012;2(3):167-70.

19. Amer S, Li TC, Ledger WL. The value of measuring anti-Mullerian hormone in women with anovulatory polycystic ovary syndrome undergoing laparoscopic ovarian diathermy. Hum Reprod. 2009;24(11):27606.

20. Kwee J, Schats R, McDonnell J, Themmen A, Jong F, Lambalk C. Evaluation of anti-Mullerian hormone as a test for the prediction of ovarian reserve. Fertil Steril. 2008;90(3):737-43.

21. Nardo LG, Gelbaya TA, Wilkinson H, Roberts SA, Yates A, Pemberton P, et al. Circulating basal antiMullerian hormone levels as predictor of ovarian response in women undergoing ovarian stimulation for in vitro fertilization. Fertil Steril. 2009;92(5):1586-93.

Cite this article as: Shankar A, Nagar O, Shakuntla, Meghwal S. Effect of laparoscopic ovarian drilling on serum anti-Mullerian hormone in clomiphene citrate resistant polycystic ovarian syndrome patients. Int J Reprod Contracept Obstet Gynecol 2021;10:3315-9. 